\title{
Newcastle Disease Virus Infection Study on Duck and Chicken in Subang District
}

\author{
Panus $\mathrm{A}^{1,2}$, Setiyaningsih $\mathrm{S}^{3}$, Mayasari NLPI ${ }^{4}$ \\ ${ }^{1}$ Graduate of Microbiology Medic, Department of Animal Disease and Veterinary, Faculty of Veterinary Medicine, Bogor Agricultural \\ University \\ ${ }^{2}$ Laboratory of Virology, Institute of Veterinary Subang, Directorate General of Livestock and Veterinary Medicine, Ministry of Agriculture \\ Jl. Terusan Garuda Blok Wepurebredari RT. 03 RW. 22 Subang, Jawa Barat \\ ${ }^{3}$ Laboratory of Virology, Section of Microbiology Medic, Department of Animal Disease dan Veterinary, Faculty of Veterinary Medicine, Bogor \\ Agricultural University, Gedung Fakultas Kedokteran Hewan Jl. Agatis Kampus IPB Dramaga, Bogor 16680 Jawa Barat \\ ${ }^{4}$ Laboratory of Imunology, Section of Microbiology Medic, Department of Animal Disease dan Veterinary, Faculty of Veterinary Medicine, \\ Bogor Agricultural University, Gedung Fakultas Kedokteran Hewan Jl. Agatis Kampus IPB Dramaga, Bogor 16680 Jawa Barat \\ E-mail: a_panus@yahoo.com
}

(received 12-01-2015; revised 13-03-2015; accepted 17-03-2015)

\begin{abstract}
ABSTRAK
Panus A, Setiyaningsih S, Mayasari NLPI. 2015. Kajian infeksi virus Newcastle Disease pada bebek dan ayam di Kabupaten Subang. JITV 20(2): 134-147. DOI: http://dx.doi.org/10.14334/jitv.v20i2.1168

Tujuan dari penelitian ini adalah untuk mendeteksi dan mengetahui keragaman antigenik virus Newcastle disease (NDV) yang bersirkulasi di Kabupaten Subang. Sampel usapan kloaka, usapan orofaring dan serum diambil dari 393 ekor ayam dan 149 bebek dari penampungan, peternakan dan pasar unggas di 10 kecamatan di Kabupaten Subang. Screening NDV pada sampel pool (5-7 individu per pool) dengan real-time Reverse-Transcription Polymerase Chain Reaction (rRT-PCR) matrix (M) menunjukkan 19 dari 67 pool kloaka $(28,3 \%)$ dan 8 dari 67 pool orofaring $(11,9 \%)$ ayam terdeteksi NDV; 18 pool dari 67 pool ayam $(26,9 \%)$ menunjukkan virus diekskresikan melalui kloaka dan orofaring. Sementara pada sampel itik, NDV terdeteksi hanya pada kloaka yaitu 8 dari 30 pool $(26,7 \%)$. Total 18 isolat berhasil diisolasi dari sampel usapan kloaka dan usapan orofaring individu yang menunjukkan karakter antigenik yang homogen, namun beberapa isolat menunjukkan variasi dengan titre sampai 2 Log2 menggunakan antisera LaSota dan 2-4 Log2 dengan antisera Komarov. Mayoritas isolat menunjukkan afinitas lebih tinggi terhadap antisera Komarov, yang mengindikasikan semua isolat adalah NDV galur ganas. Karakterisasi patogenisitas dengan uji elusi hasilnya menunjukkan 3 isolat masuk ke kelompok galur mesogenik dan 15 isolat ke kelompok galur velogenik, sedangkan dengan rRT-PCR fusion (F) menunjukkan $100 \%$ isolat merupakan galur ganas (mesogenik/velogenik). Deteksi antibodi spesifik terhadap NDV pada 408 serum dengan uji HI menunjukkan 48 serum (12\%) positif dengan kisaran titre 1 sampai $8 \log 2$; hanya sekitar $13 \%$ ayam yang divaksin menunjukkan titre protektif $(\geq 3 \log 2)$. Newcastle disease masih endemik di Kabupaten Subang dengan variasi antigenik galur virus yang bersirkulasi relatif tidak telalu bervariasi.
\end{abstract}

Kata Kunci: Newcastle Disease, rRT-PCR, Virulensi, Keragaman Antigenik, Antibodi

\begin{abstract}
Panus A, Setiyaningsih S, Mayasari NLPI. 2015. Newcastle Disease Virus infection study on duck and chicken in Subang district. JITV 20(2): 56-69 DOI:http://dx.doi.org/10.14334/jitv.v20i2.1168

The objectives of this research were to study Newcastle Disease Virus (NDV) infection in Subang area and to examine the diversity of the circulating NDV. Swabs of cloacal and oropharynx, and serum were sampled from total of 393 chickens and 149 ducks in backyard farms and live bird markets located in 10 subdistricts. Screening of NDV in pool of 5-7 samples by real-time Reverse-Transcription Polymerase Chain Reaction (rRT-PCR) matrix (M) showed 19/67 (28.3\%) cloacal and 8/67 (11.9\%) pharyngeal pools of chicken samples; $18 / 67$ (26.9\%) of the pools excreted virus via cloaca and oropharynx, while the duck pools of $8 / 30(26.7 \%)$ shed virus from cloaca. Virus isolation attempted on individual sample from positive pools yielded 18 isolates which the majority of the isolates showed homogeneous antigenic character, only some of these showed variations up to $2 \log 2$ with Lasota and $4 \log 2$ with Komarov antisera. Majority of isolates had a higher affinity to Komarov indicating their propencity to virulent strains. Pathogenicity examination using elution test showed 3 isolates virus were grouped to mesogenic strains and 15 isolates to velogenic strain, in agreement with rRT-PCR fusion results. HI test on 408 sera showed that NDV antibody was detected in $48(12 \%)$ birds with titres ranging from 1 to 8 Log2; only about $13 \%$ of vaccinated chickens demonstrated protective antibody titre $(\geq 3 \log 2)$. Newcastle disease is still endemic in Subang with relatively low antigenic variation among circulating strains.
\end{abstract}

Key Words: Newcastle Disease, rRT-PCR Detection, Detection of Virulence, Antigenic Diversity, Antibody 


\section{INTRODUCTION}

Newcastle Disease (ND) is one of serious diseases in poultry because it is very contagious, spread rapidly and attack some species of birds at all age. Mostly this outbreak attacks intensive poultry as follows: chicken, turkey, duck, quail, and pigeons. ND spread all over the world and potentially causes economy losses in poultry industry. In addition of poultry, this disease infect and causes death in wild birds as well. ND cases were firstly found and reported in the mid of 1920 in Indonesia (Java Island) and England (OIE 2012), then spreading in a few years later and becoming endemic in many countries (Ashraf \& Shah 2014). Nowadays, almost all regions in Indonesia are affected and no one area or island is free from ND. In spite of mortality rate caused by ND was controlable, the effect in production is still a problem. Moreover, the impact of other losses is the costs for controlling the disease and also stopping export from ND endemic countries (Brown et al. 1999).

The outbreak caused by ND can be acute or chronic and infecting all species of birds especially chicken, both domestic and purebred. The outbreak occured in the field may caused by various strain of ND virus. According to the severity-level of the outbreak in chicken, Newcastle Disease Virus (NDV) was classified into three pathotypes namely lentogenic, mesogenic, and velogenic. Velogenic strain is distinguished into neurotropic and viscerotropic form (Aldous \& Alexander 2001).

The loss caused by ND are morbidity and mortality which in infected poultry the rate may reach $100 \%$ caused by velogenic strain especially in sensitive chicken groups and under $10 \%$ in mesogenic strain (OIE 2008). In the developing countries where the livestock industry is growing very rapidly, the losses affected by NDV outbreak are not only mortality but also expenditure additionaly cost used for vaccination, biosecurity and depopulation. Even the free ND countries, have to spend on periodic testing in order to maintain free status from ND which needed for trading license. Moreover, in the developing countries as endemic ND, the impacts are not only economy losses but also affecting health and socioeconomic condition of lower-class society, whose quality and quantity of eggs and meat consumed decreased caused by ND (Alexander \& Senne 2008). In 2002, ND outbreak in California, United States caused losses 200.000.000 US\$ as an impact of depopulation (Kapczynski \& King 2005). The losses affected by ND in layer are mortality and reduction of egg production, while causing growth disorder and reduction of body weight in boiler. Data of OIE (2009) showed in 2007, about 1500-8000 chickens were infected by ND every month in Indonesia. Moreover, according to Xiao (2012) in 2009 and 2010, ND outbreak occured in comercial chicken in Indonesia causing $70-80 \%$ mortality. ND is still become a major problem in the poultry industry despite the vaccination carried out routinely (Samal 2011). Therefore, ND is a serious threat for poultry in Indonesia. Subang area in West Java is one of buffer zones of poultry production, particularly for broilers and layers. Totally 44.049 .739 poultry population was reported in 2013 (DISNAK 2013). Newcastle Disease is endemic in Indonesia including in Subang area. DISNAK (2013) recorded, there were 258 birds suddently died caused of ND infection in 2010 and it was confirmed by rRT-PCR using cloacal and oropharyngeal swabs and organ samples. Mass dead might occur if it was not handled properly. Annually survey by Balai Penyidikan dan Pengujian Veteriner (BPPV) Subang in unvaccinated ND backyard birds in 2011, found 10 out of 131 serums tested were positive of ND with titre range 2-5 Log2 (BPPV 2011). In 2012, 12 out of 37 serums tested were positive of ND with titre range 1-4 Log2 (BPPV 2012), and in 2013, 184 out of 359 serums tested were positive of ND with titre range 2-8 Log2 (BPPV 2013). These results show that ND is still endemic in Subang area. As the basis of consideration for efective control measures and prevention, it is neccesary to conduct NDV isolation and detection of antibody against ND in ducks and chickens in Subang area.

For the time being, investigation of ND in Subang area is still limited. Commonly, the diagnosis was based on clinical symptoms, pathological alteration and serological test. Therefore, diagnostic technique with high sensitivity to detect and confirm NDV infection in ducks and chickens in Subang area is required.

\section{MATERIALS AND METHODS}

\section{Samples}

Samples were taken from 10 subdistricts in Subang, that were Binong, Ciasem, Cipendeuy, Cipunagara, Compreng, Pagaden, Pusaka Nagara, Subang, Sukasari and Tambak Dahan. These areas were selected because population of fowls were centralized in those locations (market, shelter, farm) and endemic area of ND as well.

\section{Standard antigen and antisera and Kit}

ND virus standard (4HAU) LaSota strain (collection of FKH IPB), specific standard antisera against LaSota and Komarov strain were used for HI test (collection of BBPMSOH). QIAamp ${ }^{\circledR}$ Viral RNA Mini Kit (Qiagen) was used for RNA virus extraction. Ag-Path $\mathrm{ID}^{\mathrm{TM}}$ OneStep RT-PCR kit from Life Technologies with 96 optical plates in Applied Biosystems 7500 Real Time PCR System Software Version 1.4.0 were used for Real time RT-PCR. 


\section{Collection of swabs and serum samples}

Swabs of cloacal and oropharynx were taken from chickens and ducks from the bird's shelter, livebirds market and poultry farms in 10 areas in Subang using sterile cotton swabs inserted in microtube $2 \mathrm{ml}$ contains Brain Heart Infusion Broth (BHIB). The temperature was kept cool $\left(4-8^{\circ} \mathrm{C}\right)$ until arrival in the laboratorium.

Pooling swabs of cloacal and oropharynx samples consist of 5-7 individual samples in each pool was based on swab types, birds, location and time of sampling. The sample pool was subsequently used for rRT-PCR test using primer matrix (M). Blood was collected via branchial vein from each individu along with swab samples.

\section{real time Reverse Transcription Polymerase Chain Reaction (rRT-PCR) Test}

To detect the presence of genetic material of NDV extracted from swabs of cloacal and oropharynx, rRTPCR test with NVSL protocol (2005) was done. RNA virus isolation was extracted based on QIAamp ${ }^{\circledR}$ Viral RNA Mini Kit (Qiagen) standard procedure. rRT-PCR amplification using Ag-Path ID ${ }^{T M}$ One-Step RT-PCR kit from Life Technologies in Applied Biosystems 7500 Real Time PCR System was conducted. Cycles of rRT$\mathrm{PCR}$ was performed in $45^{\circ} \mathrm{C}$ for 10 minutes, $95^{\circ} \mathrm{C}$ for 10 minutes, $95^{\circ} \mathrm{C}$ for 10 minutes, $56^{\circ} \mathrm{C}$ for 32 seconds, and $72^{\circ} \mathrm{C}$ for 10 seconds. The result was analyzed by Applied Biosystems 7500 Real time PCR SystemSoftware Version 1.4.0. Primer and probe were used are presented in Table 1.

\section{Virus isolation in SPF embryonated chicken egg}

Swabs of cloacal and oropharynx samples used as inoculum were from individual bird sample from positive rRT-PCR M pool. As much as $0.2 \mathrm{ml}$ inoculum containing penicillin-streptomycin (9:1) and incubated for 30 minutes at ambient temperature $\left(25-27^{\circ} \mathrm{C}\right)$ was injected in allantoic cavity of Specific Pathogen Free (SPF) embryonated chicken egg. Eggs were incubated in incubator at $37^{\circ} \mathrm{C}$ for 4-7 days and observed 3 times a day to check the viability of embryo (OIE 2012). Isolates obtained from alantoic liquid were reconfirmed with rRT-PCR matrix (M).

\section{Hemagglutination (HA) and Hemagglutination Inhibition (HI) Test}

Procedures of HA and HI test was done by micro methods (OIE 2012), performed by adding $25 \mu \mathrm{l} 0.85 \%$ phosphate buffered saline (PBS) into micro plate in 1st12 th pit using micro pipet. In the 1 st pit $25 \mu \mathrm{l}$ serum standard was added and diluted, than moved into 2nd11 th pit. A total of $25 \mu \mathrm{l} 4 \mathrm{HAU}$ ND virus suspension was added into each 1st-10th and 12th pit, and then incubated at ambient temperatute for 15 minutes and 25 $\mu \mathrm{l}$ suspension of $1 \%$ red blood cells (rbc) was added into 1st-12th pit, homogenized and incubated at ambient temperature $\left(25-27^{\circ} \mathrm{C}\right)$ for 40 minutes. Positive result marked by occurance of resistance hemagglutination in form of precipitation of rbc on the bottom of micro plate pit. Titre of HI was determined based on the highest serum dilution that was still showed precipitation (agglutination inhibition). HA and HI test were performed 3 times.

\section{Elution-time test}

Test was performed based on Ezeibe \& Ndip (2005) procedures. A total of $50 \mu \mathrm{l}$ PBS solution was put into micro plate pit, then $50 \mu \mathrm{l}$ virus suspension was added into 1st pit, and diluted into 1st-10th pit. As much as 50 $\mu 1$ PBS was added into each 1st-12nd pit, followed by $50 \mu \mathrm{l}$ suspension of $0.6 \% \mathrm{rbc}$ into $1 \mathrm{st}-12 \mathrm{nd}$ pit, homogenized and incubated at ambient temperature for

Table 1. Primers and Probes used for rRT-PCR matrix $(\mathrm{M})$ and fusion $(\mathrm{F})$

\begin{tabular}{|c|c|c|c|}
\hline Target of gene & $\begin{array}{l}\text { Primer/genom probe } \\
\text { targets }\end{array}$ & Sequence $\left(5^{\prime} \rightarrow 3^{\prime}\right)$ & Reference \\
\hline \multirow[t]{3}{*}{ APMV-1 M (matrix) } & $M+4100$ forward & AGTGATGTGCTCGGACCTTC & Wise et al. (2004) \\
\hline & $M+4169$ probe matrix & $\begin{array}{c}\text { [FAM]TTCTCTAGCAGTGGG ACA GCC } \\
\text { TGC[TAMRA] }\end{array}$ & \\
\hline & M-4220 reverse & CCT GAG GAG AGG CAT TTG CTA & \\
\hline APMV-1 & $\mathrm{F}+4829$ forward & GGTGAGTCTATCCGGARGATACAAG & CVL (2007) \\
\hline \multirow[t]{2}{*}{ F (Fusion) } & $F+4939$ reverse & AGCTGTTGCAACCCCAAG & \\
\hline & $\begin{array}{l}\text { F+4894 Probe } 1 \\
\quad \text { (Virulent) }\end{array}$ & $\begin{array}{c}\text { [FAM]AAGCGTTTCTGTCTCCTTCCTCCA } \\
\text { [TAMRA] }\end{array}$ & \\
\hline
\end{tabular}


40 minutes, then hemagglutination was observed. Elution time was determined based on time of complete hemagglutination was observed on highest dilution until the precipitation of rbc showed (elution). Elution-time test was performed 3 times.

\section{Data analysis}

Data were analyzed descriptively and statistically to determine standard mean deviation (SD). The average of antibody titre was calculated by geometric mean titre (GMT) by the formula:

$\log 2 \mathrm{GMT}=\underline{(\log 2 \mathrm{t} 1)(\mathrm{S} 1)+(\log 2 \mathrm{t} 1)(\mathrm{S} 1)+\ldots+(\log 2 \mathrm{tn})(\mathrm{Sn})}$

Information: $\mathrm{N}=$ Number of observed serum

$\mathrm{T}=$ Antibody titre at the highest dilution (which was still may inhibit agglutination of red blood cell)

$\mathrm{S}=$ Number of titrated serum

$\mathrm{n}=$ Antibody titre of the $\mathrm{n}^{\text {th }}$ sample

Coefficient of variation/CV from immune response was expressed by following formula:

$$
\mathrm{CV}=\frac{\mathrm{S}}{\overline{\mathrm{X}}} \times 100 \%
$$

Description:

$\begin{aligned} \mathrm{CV} & =\text { Coefficient of Variant, } \\ \mathrm{S} & =\text { Standard Deviation, } \\ \overline{\mathrm{X}} & =\text { Average of antibody titre }\end{aligned}$

\section{RESULT AND DISCUSSION}

\section{Detection of NDV in pool of swabs of cloacal and oropharynx with rRT-PCR matrix (M)}

There were 542 samples succesfully collected consist of 149 ducks and 393 chickens sample comprised of 108 broilers, 148 broiler parent stocks, 15 layers and 122 lokal chickens from 10 areas in Subang district.

Testing for 97 pools swabs of cloacal resulted in 27 pools $(29 \%)$ of positive which spreaded in 9 areas, 8 pools $(7 \%)$ oropharynx swabs positive spreaded in 3 areas and 18 pools (18\%) of cloacal and oropharynx swabs positive spreaded in 6 areas while none was positive from Cipendeuy area (Table 2 ). ND virus was only detected in cloacal swabs of ducks (8/30 pools), 19 pools cloacal swabs, 8 pools oropharynx swabs and 18 pools cloacal and oropharynx swabs (Table 1). Ducks tend to excrete the virus via cloaca according to the findings reported by Saepulloh \& Darminto (2005) which were $14(13 \%)$ isolates from cloacal and none from oropharynx swabs of 106 ducks in Kalimantan.

The highest number of positive $M$ cloacal swabs pools (7) were obtained from Tambak Dahan area. The highest number of positive $\mathrm{M}$ oropharynx swabs pools (4) were obtained from Cipunagara area and the highest number of positive $\mathrm{M}$ cloacal and oropharynx swab pools (8) were obtained from Binong area, while in Cipendeuy area in pool of cloacal or oropharynx swabs, NDV were not detected.

\section{Isolation of NDV in SPF embryonated chicken eggs}

NDV virulence could be determined based on the infected embryo's death time. According to Cattoli et al. (2011), NDV causing embryo's death in more than 90 hours after inoculation was grouped in to lentogenyc strain, and between 60-90 hours grouped in to mesogenyc strain, while less than 60 hours, was grouped into velogenyc strain.

Inoculation of 128 cloacal swabs positive rRT-PCR M, 10 isolates were obtained, and from 76 positive oropharynx swabs, 8 isolates obtained. Totally, $18 \mathrm{NDV}$ were succsessfully isolated and they were 3 isolates from 3 ducks and 15 isolates from chickens. The virus excreted via chicken's cloaca and oropharynx was balanced; 7 isolates from native chicken cloaca and oropharynx, 6 isolates from broiler oropharynx and 2 isolates from 2 native chicken oropharynx. Four out of 18 isolates were excreted from cloacal and oropharynx from 2 native chickens. In Binong area, pool of cloacal and oropharynx swabs sample were not contain NDV (negative rRT-PCR M) so isolates were not obtained from layer (Table 1). Transmission route of virus from the host body affected by tropism tissue of NDV. The virus which is replicated in respiratory tract will be shed through mouth and nostril and NDV replicated in digestive tract will be shed through cloaca. During incubation, virus replicated at the entry site. Virulent NDV strain (mesogenyc and velogenyc) could invaded into blood vessels, following the blood circulation and replicated in visceral organs, then excreted through the feces (Alexander \& Senne 2008). The replication of virulent NDV strain in visceral organs causes tissue damage, such as lesions in brain, hemorrhage and necrosis of the intestinal tract, respiratory and caeca tonsils. Haemorrhage can be found in the craw, heart, skin and eyelids as well (Figure 1). 
Table 2. The number of birds and pool sample from 10 subdistricts in Subang with rRT-PCR M test results and number of NDV isolates with antibody titre from individual of NDV detected

\begin{tabular}{|c|c|c|c|c|c|c|c|}
\hline \multirow{3}{*}{ District } & \multicolumn{2}{|c|}{$\sum$ Birds/Pool } & \multirow{2}{*}{\multicolumn{3}{|c|}{$\begin{array}{c}\begin{array}{c}\sum \text { pool matrix with } \\
\text { the result }(+)\end{array} \\
\text { Duck/Chicken }\end{array}$}} & \multirow{3}{*}{$\begin{array}{c}\begin{array}{c}\sum \text { Isolate was } \\
\text { obtained }\end{array} \\
\text { Duck/Chicken }\end{array}$} & \multirow{3}{*}{ Type of sample } \\
\hline & \multirow{2}{*}{ Duck } & \multirow{2}{*}{ Chicken } & & & & & \\
\hline & & & $\mathrm{C}$ & $\mathrm{O}$ & $\mathrm{C} \& \mathrm{O}$ & & \\
\hline Ciasem & $22 / 4$ & $2 \mathrm{Kp} / 1$ & $1 / 1$ & $0 / 0$ & $0 / 0$ & $1 / 0$ & $\mathrm{C}$ \\
\hline Pusaka Negara & $24 / 5$ & - & $2 / 0$ & $0 / 0$ & $0 / 0$ & $1 / 0$ & $\mathrm{C}$ \\
\hline Sukasari & $22 / 5$ & - & $5 / 0$ & $0 / 0$ & $0 / 0$ & $1 / 0$ & $\mathrm{C}$ \\
\hline Tambak Dahan & $31 / 7$ & $57 \mathrm{Kp} / 12$ & $0 / 6$ & $0 / 1$ & $0 / 1$ & 0/2 Kp & $2 \mathrm{C}$ \\
\hline \multirow[t]{2}{*}{ Binong } & - & $15 \mathrm{~L} / 3$ & $0 / 0$ & $0 / 0$ & $0 / 0$ & $0 / 0$ & - \\
\hline & - & $86 \mathrm{Br} / 13$ & $0 / 3$ & $0 / 3$ & $0 / 8$ & 0/4 $\mathrm{Br}$ & 40 \\
\hline Compreng & - & $20 \mathrm{Kp} / 4$ & $0 / 1$ & $0 / 0$ & $0 / 1$ & $0 / 2 \mathrm{Kp}$ & $1 \mathrm{C} \& 1 \mathrm{O}$ \\
\hline Pagaden & - & $15 \mathrm{Kp} / 3$ & $0 / 1$ & $0 / 0$ & $0 / 1$ & 0/3 Kp & $1 \mathrm{C}, 1 \mathrm{C} \& 1 \mathrm{O}$ \\
\hline \multirow[t]{2}{*}{ Cipunagara } & $23 / 4$ & $18 \mathrm{Br} / 3$ & $0 / 0$ & $0 / 0$ & $0 / 0$ & $0 / 0$ & - \\
\hline & - & 153 Br. PS /22 & $0 / 4$ & $0 / 4$ & $0 / 5$ & 0/2 Br.PS & $2 \mathrm{O}$ \\
\hline Cipeundeuy & $27 / 5$ & - & $0 / 0$ & $0 / 0$ & $0 / 0$ & $0 / 0$ & - \\
\hline Subang & - & $27 \mathrm{Kp} / 6$ & $0 / 3$ & $0 / 0$ & $0 / 2$ & 0/2 Kp & $2 \mathrm{C}$ \\
\hline Total & $149 / 30$ & 393 / 67 & $8 / 19$ & $0 / 8$ & $0 / 18$ & $3 / 15$ & \\
\hline
\end{tabular}

$\mathrm{Kp}=$ kampong; $\mathrm{L}=$ layer; $\mathrm{Br}=$ broiler; $\mathrm{PS}=$ parent stock; $\mathrm{C}=$ cloaca; $\mathrm{O}=$ oropharyn $\mathrm{x}$

According to Pertulla (2009) percentage of mortality due to infection of velogenyc NDV strain could reached $90 \%$ and usually the infected birds will die in 1-2 days after infection. Isolation NDV from swabs of bird cloacal and oropharynx samples from the field in Bangladesh have been done by Haque at al. (2010), and the result showed that 18 isolates were obtained from 20 cloacal swabs and 17 isolates from 20 oropharynx swabs.

ND virus found in unvaccinated native duck was originated from natural infection and usually mesogenyc or velogenyc NDV strain infection in duck showed no clinical symptoms (Saepulloh \& Darminto 2005). The NDV isolated from unvaccinated native chickens was also from natural infection. Detection of NDV with RT-PCR has been performed by Kencana et al. (2012) from 10 native chickens in acute-field case with short incubation period (1-2 days) reported and the result showed ND positive. Additionally, Adi et al. (2010) also succed in isolating velogenic NDV strain from native chicken when ND outbreak occur in Bali, and stated that keeping of free-range chicken tends to increase the opportunities for contact with other poultry which has potential risk in the transmission of ND. NDV also found in broilers and parent stocks which had been vaccinated. The chickens were still infected by ND even though it had been vaccinated. It seemed that the vaccination had been carried out was less effective. According to Dortmans et al. (2012), the main cause of the failure of vaccination is caused by improper vaccination implementation and also vaccinated chickens with low antibody usually vulnerable to NDV infection. While according to $\mathrm{Hu}$ et al. (2011), the NDV still found in vaccinated chickens because of the shedding of vaccine virus which not homologous with field virus. This was evidenced by Miller et al. (2013) experimentally by vaccinating chickens with LaSota vaccine, and then the chickens were challenged with heterologous virulent NDV (CA/2002) which different genotype with the vaccine virus and the result showed the challenge virus was still excreted into environment and infect unvaccinated chickens (control). According to Miller et al. (2013) using homologous vaccine with field virus may decrease excretion of virus into 
environment more than heterologous vaccine. Most of ND vaccine not prevent vaccinated birds from virulent NDV infection but vaccination significantly may decrease the amount of virus excreted through saliva and feces compared to unvaccinated birds (Kapczynski \& King 2005; Miller et al. 2009).

NDV was successfully isolated from ducks and chickens showed with and without illness symptoms. According to Emilia (2013), virus was found in the sample from the birds that did not show clinical symptom, possibly due to effect of partial infection in birds, so clinical symptom did not appear, however the virus still excreted. Saepulloh \& Darminto (2005) stated that if the NDV can be detected in sick bird feces (cloaca), then this indicated of systemic infection.

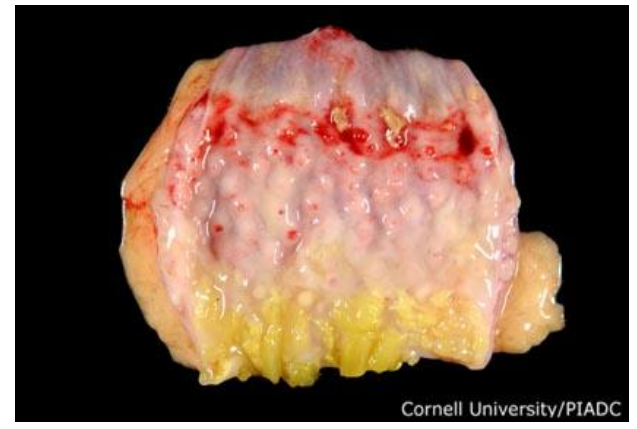

(a)

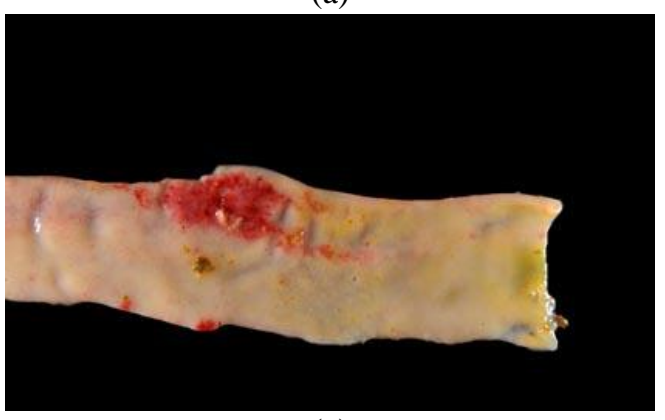

(c)

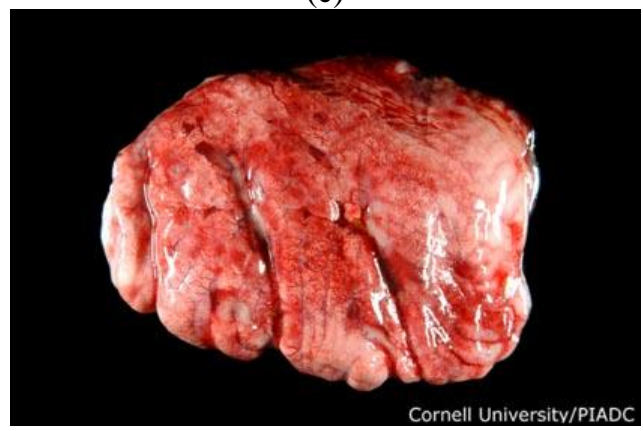

(e)
Only 18 isolates successfully isolated from 204 (9\%) swabs of cloacal and oropharinx that positive of $M$ and inoculated into embryonated chicken eggs (Table 1), it was due to a lot of NDV did not multiplicate in eggs because of the virus already inactive due to the handling and transport of samples were unfavorable. A similar incident also occured in Emilia (2013) study, from 20 samples of individual that positive of gen matrix $(\mathrm{M})$ which were inoculated in eggs, only 11 isolates were successfully isolated. This showed that the tRT-PCR test may detect inactive virus, according to Indriani et al. (2014) one of the advantages of rRT-PCR is able to detect genetic materials of virus either active or inactive. Detection of Antibody with Hemagglutination Inhibition Test (HI).

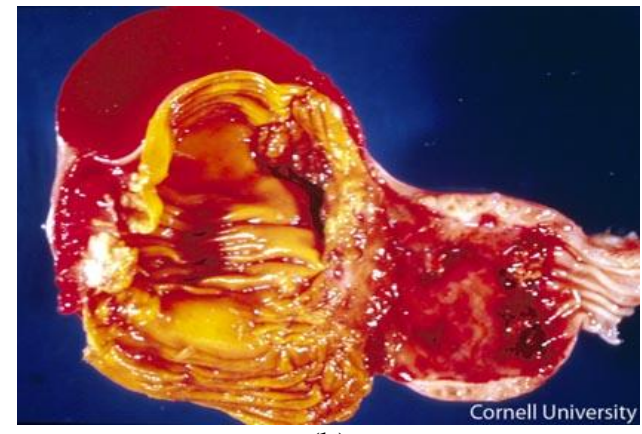

(b)

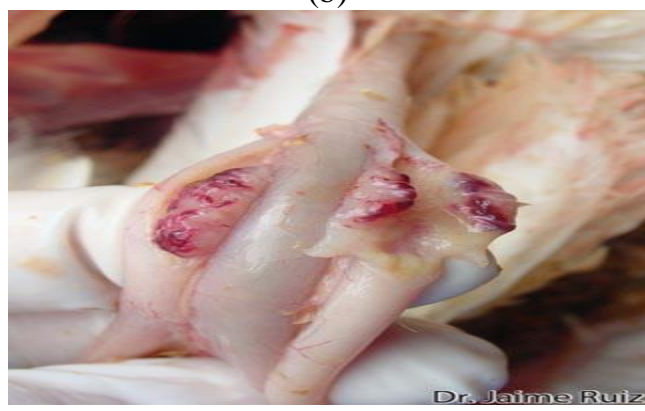

(d)

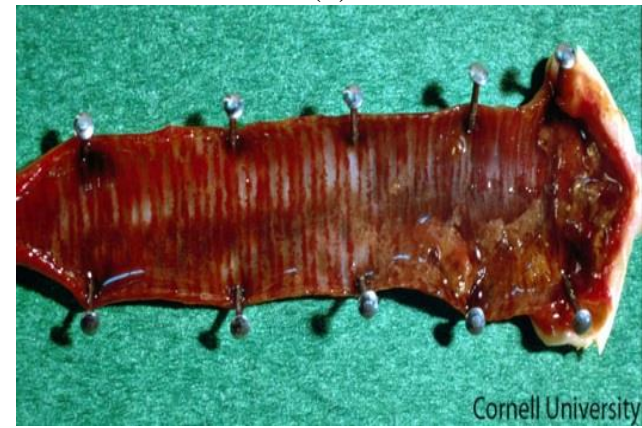

(f)

Figure 1.Patognomonis pathological alteration of Newcastle Disease infection. Ptechie in proventriculus (a); ventriculus (b); intestine (c); caeca tonsil (d); oropharhynx (e); and lung (f) (Buckles et al. 2005) 
HI test is often used in laboratories to examine specific antibody titres against NDV because its more specific and does not require special equipment so more economic (Syukron et al. 2013). The serums tested were selected based on representation of the flocks which detected positive and negative of NDV with rRT-PCR from each area. Distribution of antibody classified into three, namely: group 0, meaning that antibodies were not detected, <3, meaning low and no protective antibodies, and $\geq 3$ groups, meaning that protective antibodies (Boven et al. 2008; Rezaeianzadeh et al. 2011).

HI test result on 403 serums from 10 areas showed that 48 serums $(12 \%)$ containing varied titre antibody; 37 with $\geq 3 \log 2$ titre and 11 with $<3 \log 2$ titre (Table $3)$. Antibodies against NDV detected in waterfowl (ducks), in the chickens were not vaccinated, and in vaccinated domestic birds. Antibodies against NDV detected in 9 of 18 duck serums from Pusaka Nagara area tested the spreading of 8 serums with $\geq 3 \log 2$ titre and 1 serum with $<3 \log 2$ titre, at 1 of 17 ducks serum and 1 of 32 chicken serums tested from Tambak dahan area with each $\geq 3 \log 2$ titre, at 10 of 62 broiler serums from Binong area tested with the spread of 5 serums with $\geq 3 \log 2$ titre and 5 serums with $<3 \log 2$ titre. in 1 of 13 chicken serum from Pagaden area tested with $\geq 3$ $\log 2$ titre, in 26 of 135 broiler breeders (parents stock) serum from Cipunagara area tested with the spreading of 21 with $\geq 3 \log 2$ titre and 5 with $<3 \log 2$ titres. Sample of cloacal and oropharyngeal swab and serum taken from a total of 27 ducks from Cipeundeuy area not found for NDV and content of specific antibodies against ND. This shows that duck samples from Cipeundeuy area were free from NDV. However, to ascertain whether the Cipeundeuy area is free of ND, it is necessary to do the detection and isolation of NDV and detection of specific antibodies against NDV in ducks and other birds such as native chicken and purebred chicken from other locations in Cipeundeuy area.

The percentage of total chicken serum that positively detected specific antibody against NDV $(17 \%)$ was higher than the waterfowl $(10 \%)$ and native chicken $(2 \%)$. In vaccinated broilers, out of 212 serums tested only 36 serums containing antibodies against NDV, which 10 of them (28\%) showed a low titre. This is because the serums were taken from culled broiler breeders which was not re-vaccinated of ND (live and killed vaccine) so antibody titre had been decreased, besides the serums were taken from broilers which had just only once ND vaccination and performed at day old with spray method using live ND vaccine and was not re-vaccinated (booster), so the possibility of uneveness of the titres is caused of antibody began to decline.

In waterfowl, only 3 isolates were successfully obtained from $8 \%$ positive of $\mathrm{M}$ cloacal pools and no isolates obtained from $1 \%$ positive of $\mathrm{M}$ oropharynx pools. In native chicken, it were 7 isolates obtained from $17 \%$ positive of $\mathrm{M}$ cloacal pools and 2 isolates obtained from 16 positive of $M$ oropharinx pools. In broiler, there was not isolate obtained from $20 \%$ positive of $\mathrm{M}$ cloacal pools and 6 isolates obtained from $19 \%$ positive of $\mathrm{M}$ oropharinx pools (Table 3 ). There were not a lot of isolates of NDV were obtained, even there was some that not successfully obtained from positive of rRT-PCR M cloacal and oropharinx pools from flocks were also positively detected antibodies against NDV.

Value of coefficient of variation (CV) may used to describe the distribution of antibody titres in groups of animals. Mean and distribution of antibody titres in broilers using Geometric Mean Titre (GMT) and Coefficient of Varian (CV) calculations may be seen in Table 3.

Examination of 212 serum samples of native chicken from Binong and Cipunagara area showed that the average titres were low, ranging from 0-2.8. CV value of the lowest antibody titres was seen in flock of broiler chickens aged 3 weeks from the Binong area. It was $45.3 \%$ and the highest seen in culled PS broiler chickens flocks in Cipunagara. It was $185 \%$, while the layer chicken flocks and broiler flocks from the Binong area and in broiler flock in Cipunagara area showed the mean titre of 0 and titres distribution of 0 , due to the antibodies in the serum was not detected. CV value of antibody titres from broiler flock in Binong area $(45.3 \%)$ and broiler flock in Cipunagara area $(185 \%$ and $49.9 \%$ ) were look $\geq 35 \%$. This shows that distribution of antibody titres uneven well. The results of the average titre and distribution of antibody titres of vaccinated broilers in Binong and Cipunagara area were low and did not spreading well. It showed that vaccination of ND in broilers in both of Binong and Cipunagara subdistricts were not optimal.

HI titre showed the immunity status of bird. In unvaccinated native bird and did not show illness symptom, the existence of antibody indicated that the bird had been ever exposed by NDV (Alexander et al. 2004). In vaccinated birds with antibody titre at $\geq 3$ Log2 level indicated a protective antibody. Herd immunity in a population is very important to be protected from the NDV. According to Boven et al. (2008) herd immunity will be obtained if $85 \%$ or more of antibody titre was at $\geq 3 \log 2$ level after twice vaccination. Kapczynski \& King (2005) reported a field case which showed that only birds with anti body titre at $\geq 4 \log 2$ level and flock which has group immunity at $66 \%$ minimal which resistant to virulent NDV infection after many times vaccination. Generally, antibody titre $\geq 5 \log 2$ was considered the most protective. A phenomenon where flock of birds with high antibody titre is still may infected by virulent NDV or opposite of 
Table 3. The result of detection antibody specific against NDV in bird serums from 10 areas in Subang area according to poultry commodities

\begin{tabular}{|c|c|c|c|c|c|c|c|c|c|c|c|}
\hline \multirow{3}{*}{ Type/commodites } & \multirow{2}{*}{\multicolumn{2}{|c|}{$\%$ Pool M + }} & \multirow{2}{*}{\multicolumn{2}{|c|}{ Isolate }} & \multirow{3}{*}{$\begin{array}{c}\text { Programe } \\
\text { Vaccination }\end{array}$} & \multirow{3}{*}{$\begin{array}{c}\sum \\
\text { Serum } \\
\text { Tested }\end{array}$} & \multirow{3}{*}{$\begin{array}{l}\sum \\
+ \\
\end{array}$} & \multirow{3}{*}{$\begin{array}{l}\% \\
+ \\
\end{array}$} & \multirow{2}{*}{\multicolumn{3}{|c|}{$\begin{array}{c}\text { Antibody titre } \\
\log 2\end{array}$}} \\
\hline & & & & & & & & & & & \\
\hline & $\mathrm{C}$ & $\mathrm{O}$ & $\mathrm{C}$ & $\mathrm{O}$ & & & & & 0 & $<3$ & $\geq 3$ \\
\hline Waterfowl & 8 & 1 & 3 & - & No & 102 & 10 & 10 & 92 & 1 & 9 \\
\hline Native chicken* & 17 & 6 & 7 & 2 & No & 94 & 2 & 2 & 92 & - & 2 \\
\hline Purebred chicken & 20 & 19 & - & 6 & Yes & 212 & 36 & 17 & 176 & 10 & 26 \\
\hline Total & 45 & 26 & 10 & & & 408 & 48 & 12 & 360 & 11 & 37 \\
\hline
\end{tabular}

$\mathrm{C}=$ cloacal; $\mathrm{O}=$ oropharynx; *the native chicken in Subang area were not vaccinated of ND since 2004

Table 4. The result of mean and distribution antibody titre of vaccinated broiler in Subang area using geometric mean tire (GMT) and coefficient of variation $(\mathrm{CV})$

\begin{tabular}{|c|c|c|c|c|c|c|c|c|c|}
\hline \multirow{3}{*}{ Subdistrict } & \multirow{3}{*}{$\begin{array}{l}\text { Type of } \\
\text { chicken }\end{array}$} & \multirow{3}{*}{ Age } & \multirow{3}{*}{$\begin{array}{c}\sum_{\text {Population }} \\
\text { (individual) }\end{array}$} & \multirow{2}{*}{\multicolumn{2}{|c|}{$\begin{array}{c}\% \\
\text { Pool+ M } \\
\end{array}$}} & \multirow{3}{*}{$\begin{array}{c}\sum \\
\text { Tested } \\
\text { serum }\end{array}$} & \multirow{3}{*}{$\begin{array}{c}\text { Range } \\
\begin{array}{c}\text { Antibody } \\
\text { titre }\end{array} \\
(\log 2)\end{array}$} & \multirow{3}{*}{$\begin{array}{l}\text { GMT } \\
(\log 2)\end{array}$} & \multirow[b]{2}{*}{$\mathrm{CV}$} \\
\hline & & & & & & & & & \\
\hline & & & & $\mathrm{C}$ & $\mathrm{O}$ & & & & $\%$ \\
\hline Binong & Layer & $40 \mathrm{mg}$ & 120 & 0 & 0 & 15 & 0 & 0 & 0 \\
\hline Binong & Broiler & $2 \mathrm{mg}$ & 10.000 & 80 & 20 & 35 & 0 & 0 & 0 \\
\hline Binong & Broiler & $3 \mathrm{mg}$ & 20.000 & 75 & 87 & 50 & $0-7$ & 0.8 & 45.3 \\
\hline Cipunagara & Broiler & $2 \mathrm{mg}$ & 18.000 & 0 & 0 & 8 & 0 & 0 & 0 \\
\hline Cipunagara & $\begin{array}{c}\text { Broiler } \\
\text { PS }\end{array}$ & culled & 14.150 & 64 & 27 & 30 & $0-5$ & 1.1 & 185 \\
\hline Cipunagara & $\begin{array}{l}\text { Broiler } \\
\text { PS }\end{array}$ & culled & 950 & 40 & 70 & 64 & $0-8$ & 2.8 & 49.9 \\
\hline Total & & & & & & 212 & & & \\
\hline
\end{tabular}

$\mathrm{CV} \leq 35 \%=$ sebaran of homogenous titre; $\mathrm{CV}>35 \%=$ sebaran of not homogenous titre

it, where the flock with low antibody titre is protective against NDV, in field was still occur often (Yan et al. 2011). Besides, according to Reynolds \& Maraga (2000) and Erf (2004) experimentally showed there was no directly correlation between antibody titre in serums against chicken immunity which was challenged with NDV.

Antibody titre response is strongly influenced by quality of vaccine, route and the implementation of application, the environment, individual's factor and the species of bird (OIE 2012). Massal vaccination using live vaccine is often used than individually vaccine, because it is cheaper and easier to be applied (Senne et al. 2004). Vaccine from virulent strain (LaSota and B1) is commonly used around the world to overcome ND because it can provide protection to virulent NDV if the vaccination is done correctly (Kapczynski \& King 2005; Cornax et al. 2012; Dortmans et al. 2012). In reality, sometimes the results are not as expected, mass vaccination using spray method showed that the percentage of group immunity was $53 \%$, whereas vaccination by drinking water showed that the percentage of group immunity was $60 \%$ (Degefa et al. 2004). Ineffective vaccination also may be affected by immunosuppressive conditions of birds (Perozo et al. 2012). Beside live vaccine, inactive vaccine is also often used in layer and breeder farming because it may provide longer high titre than the live vaccine and the antibody can be downgraded to their generation (AlGarib et al. 2003). But inactive vaccine is expensive and its application must be done individually, so not all breeders can use it. Alike serology survey in vaccinated broiler and layer chicken in Faisalabad was also done by Numan et al. (2005), the result showed that antibody titre was varies in two types of the bird, but the majority antibody titre was $\geq 3 \log 2$. Aziz \& Ahmed (2010) did 
the serology survey of unvaccinated domestic chicken in Sulaiman Province, Irak. The result showed that serum of 500 tested chickens, 172 serums (34\%) was detected antibody. This shows that ND still endemic in Irak.

The existence of a positive antibody specific to NDV in unvaccinated duck and native chicken serums showed that in Subang was vulnerable of ND. This is because the duck and chicken were positive for antibody against NDV may be a carrier which became a source of Newcastle disease spreading (Saepulloh \& Darminto 2005; Adi et al. 2010).

Observing the presence of antibodies in 16 birds that excreting NDV from 9 sub districts showed that only 4 individual from 3 sub districts were positive with varying titres (Table 5). The antibody was detected in unvaccinated duck and did not show symptoms of illness from Sukasari area with antibody titre $2 \log 2$ (isolate 3), two weeks old vaccinated broiler chicken with illness symptom from Binong area with titre 3 $\log 2$ (isolate 7), three weeks old vaccinated broiler chicken with illness symptom with titre $8 \log 2$ (isolate 8 ) and 12 weeks old vaccinated breeding broiler (parent stock) and showed illness symptom with titre $5 \log 2$ from Cipunagara (isolate 13) (Table 5). The existence of antibody in unvaccinated duck and was successfully isolated of NDV showed an immune response of ongoing NDV infection, while the detection of antibody in unvaccinated chickens and ducks where NDV was not found, according Rezaeianzadeh et al. (2011), it showed that NDV infection that has passed and the birds were able to survive and recovery from NDV infection. In the unvaccinated birds where NDV was not detected, according to Daulay (2005) who was successfully isolated NDV from 2 wild birds (pigeon and turtle doves) showed antibody titre $0 \log 2$ was due to infection process has not been occurred, so the antibody has not been produced. In 3 vaccinated domestic chickens and detected of antibody against NDV, showed high titre antibody in the range 3-8 Log2 may still excrete virus through the cloaca and oropharynx. This may be affected by ineffective vaccination due to vaccine virus with field NDV was not homologous, so virus shedding occurred. Antibody response was not formed due to suboptimal vaccination, so that the chickens may be infected by NDV according to no detected antibody of vaccinated domestic chickens and isolated of NDV. The result of testing sample serum by HI test which successfully isolated from NDV may be seen in Table 4.

\section{Antigenic diversity}

Homologous antiserum will has an higher affinity with the viral surface epitopes so its more optimal inhibiting hemagglutination activity. Characterization of 18 antigen isolates with the HI test using antisera Lasota (lentogenic) obtained the average (mean) of HI titres between 6-8 $\log 2$ with antisera and Komarov (mesogenic) between 9-13 $\log 2$. Isolates affinity with LaSota antisera showed relatively homogeneous antigenic character, only a few isolates that showed variation reaches $2 \log 2$ (1st, 2nd, and 3rd isolate), as well as antisera Komarov, only a few isolates that showed variation reaches $4 \log 2\left(3 \mathrm{rd}, 6^{\text {th }}\right.$, and 16 th isolate). All NDV isolates showed a higher affinity against antisera Komarov compared with Lasota antisera that indicates all the NDV tend to get into a virulent NDV strain (Figure 2). According to Alexander \& Senne (2008) differences of antigenic between NDV strains which may be recognized by specific antibodies determined by a hemagglutinin (HN) protein. Beside it, according Adu (1985) and Ibu et al. (2008) antigenic variation in NDV from the same strainoccurs because of various functions of the external proteins due to mutation.

Study of the antigenic diversity of NDV using polyclonal antisera had been conducted by Emilia (2013) using antisera strain Lasota, Komarov, the G7 and the ITA against four isolates Serpong area, West Java. The result showed that varies affinity with HI titres ranging between 3-5 $\log 2$ (Lasota), 5-10 $\log 2$ (Komarov), 6-8 $\log 2$ (G7) and 3-7 $\log 2$ (ITA). HsiangJung et al. (2004) examined the variation of antigenic against 36 isolates from Taiwan NDV obtained between 1969-1996 using 22 monoclonal antibodies (MAB) and was able to separate the 36 isolates into 18 groups antigenic and based on the nucleotide sequences of gene $F$ were grouped into 15 genotypes. Characterization of NDV antigen may also be done with a monoclonal antibody (MBA). Hu et al. (2010) showed using four types of MBA, that NDV antigenic variation may occur due to mutations of residues K (Lysine) at position 347 in the $\mathrm{HN}$ protein.

\section{Characterization of physical properties of ND Virus with Elution Time Test}

Determination of NDV strain may be known by its biological activity, including by elution time test. Significantly different in the time value may be used to distinguish of NDV strain on field roughly. According to Ezeibe \& Ndip (2005) elution time of velogenic patotype virus had elution time between 84-189 minute, while mesogenic virus had elution time between $45-78$ minute and virus that includes lentogenic (LaSota) had elution time for 20-43 minutes. Characterization of the pathogenicity of 18 isolates with elution showed 3 isolated include mesogenic group and 15 isolates to velogenic group (Table 5). Observing the elution time of isolates obtained from cloacal and oropharyngeal swabs from 1 native chicken in Compreng area (isolate 
Table 5. Result of detection of specific antibody against NDV with HI test in 16 bird's serums which successfully isolated of NDV in Subang area

\begin{tabular}{|c|c|c|c|c|c|}
\hline \multirow[b]{2}{*}{ District } & \multirow[b]{2}{*}{ Type of bird } & \multirow{2}{*}{$\frac{\%}{\text { Pool+ M }}$} & \multirow{2}{*}{$\frac{\text { Antibody }}{\text { Titre }(\log 2)}$} & \multicolumn{2}{|c|}{ Isolate } \\
\hline & & & & Code & $\begin{array}{l}\text { Type of } \\
\text { sample }\end{array}$ \\
\hline Ciasem & Duck & $40 \%$ & 0 & 1 & $\mathrm{C}$ \\
\hline Pusaka Negara & Duck & $40 \%$ & 0 & 2 & $\mathrm{C}$ \\
\hline Sukasari & Duck & $80 \%$ & 2 & 3 & $\mathrm{C}$ \\
\hline Tambak Dahan & Kp. chicken & $42 \%$ & 0 & 4 & $\mathrm{C}$ \\
\hline Tambak Dahan & Kp. chicken & $42 \%$ & 0 & 5 & $\mathrm{C}$ \\
\hline Binong & Broiler & $69 \%$ & 0 & 6 & $\mathrm{O}$ \\
\hline Binong & Broiler & $69 \%$ & 3 & 7 & $\mathrm{O}$ \\
\hline Binong & Broiler & $69 \%$ & 8 & 8 & $\mathrm{O}$ \\
\hline Binong & Broiler & $69 \%$ & 0 & 9 & $\mathrm{O}$ \\
\hline Compreng & Kp. chicken & $50 \%$ & 0 & $10 \mathrm{a}$ & $\mathrm{C}$ \\
\hline Compreng & Kp. chicken. & $25 \%$ & 0 & $10 \mathrm{~b}$ & $\mathrm{O}$ \\
\hline Pagaden & Kp. chicken & $67 \%$ & 0 & 11 & $\mathrm{C}$ \\
\hline Pagaden & Kp. chicken & $66 \%$ & 0 & $12 \mathrm{a}$ & C \\
\hline Pagaden & Kp. chicken & $67 \%$ & 0 & $12 \mathrm{~b}$ & $\mathrm{O}$ \\
\hline Cipunagara & Broiler Ps. & $31 \%$ & 5 & 13 & $\mathrm{O}$ \\
\hline Cipunagara & Broiler Ps. & $31 \%$ & 0 & 14 & $\mathrm{O}$ \\
\hline Subang & Kp. chicken & $83 \%$ & 0 & 15 & $\mathrm{C}$ \\
\hline Subang & Kp. chicken & $83 \%$ & 0 & 16 & $\mathrm{C}$ \\
\hline
\end{tabular}

$\mathrm{Kp}=$ kampong; $\mathrm{Ps}=$ parent stock; $\mathrm{C}=$ cloaca; $\mathrm{O}=$ oropharynx

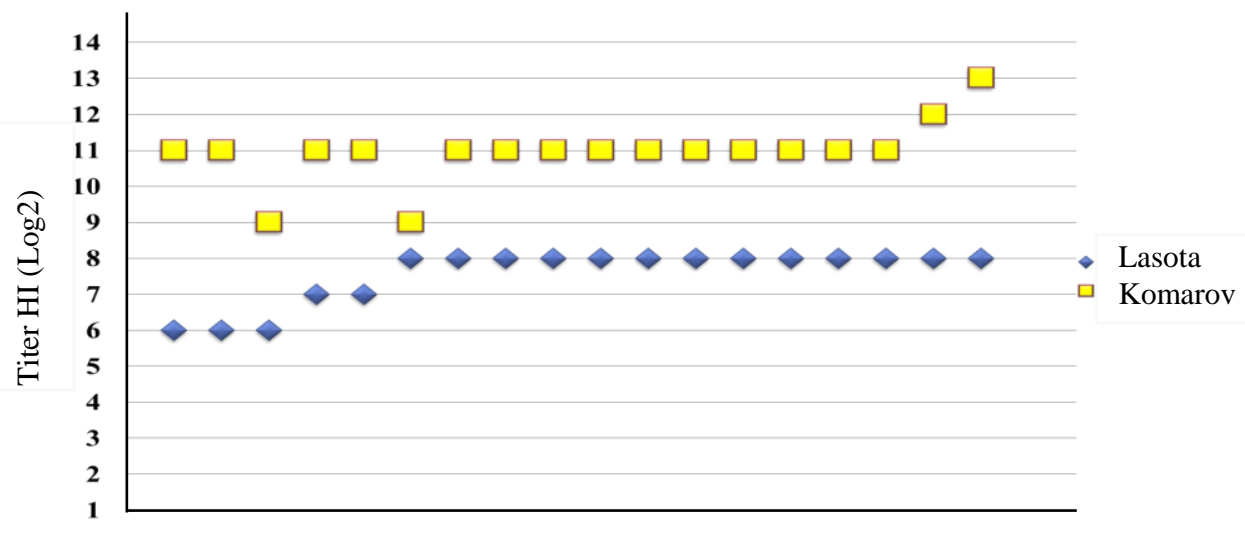

Code of Isolates

Figure 2. Comparison of antigenic of 18 isolates with $\mathrm{HI}$ test. The majority of $\mathrm{HI}$ titres looks homogeneous, only a few isolates that showed a variation with the antisera Lasota $2 \log 2$ and with antisera Komarov $4 \log 2$. HI titre comparison of both antisera showed isolates tend to lead to a virulent strain 
Table 6. The result of elusion time test of NDV isolates that obtained from chicken and duck in 10 areas in Subang area

\begin{tabular}{|c|c|c|c|c|c|}
\hline \multirow{2}{*}{ District } & Type of & Code of & Type of & Elusion time & Type of \\
\hline & Bird & isolate & samples & (minute) & Patotipe \\
\hline Ciasem & Duck & 1 & $\mathrm{C}$ & $117 \pm 0.0$ & Velogenic \\
\hline Pusaka Negara & Duck & 2 & $\mathrm{C}$ & $119 \pm 0.0$ & Velogenic \\
\hline Sukasari & Duck & 3 & $\mathrm{C}$ & $162 \pm 0.0$ & Velogenic \\
\hline Tambak Dahan & Kp. Chicken & 4 & $\mathrm{C}$ & $165 \pm 5.2$ & Velogenic \\
\hline Tambak Dahan & Kp. Chicken & 5 & $\mathrm{C}$ & $117 \pm 0.0$ & Velogenic \\
\hline Binong & Broiler & 6 & $\mathrm{O}$ & $89.6 \pm 23.7$ & Velogenic \\
\hline Binong & Broiler & 7 & $\mathrm{O}$ & $225 \pm 0.0$ & Velogenic \\
\hline Binong & Broiler & 8 & $\mathrm{O}$ & $232 \pm 12.1$ & Velogenic \\
\hline Binong & Broiler & 9 & $\mathrm{O}$ & $105 \pm 0.0$ & Velogenic \\
\hline Compreng & Kp. Chicken & $10 \mathrm{a}$ & $\mathrm{C}$ & $219 \pm 0.0$ & Velogenic \\
\hline Compreng & Kp. Chicken & $10 \mathrm{~b}$ & $\mathrm{O}$ & $262.3 \pm 0.0$ & Velogenic \\
\hline Pagaden & Kp. Chicken & 11 & $\mathrm{C}$ & $117 \pm 0.0$ & Velogenic \\
\hline Pagaden & Kp. Chicken & $12 \mathrm{a}$ & $\mathrm{C}$ & $80 \pm 0.0$ & Mesogenic \\
\hline Pagaden & Kp. Chicken & $12 b$ & $\mathrm{O}$ & $70 \pm 0.0$ & Mesogenic \\
\hline Cipunagara & Kp. Chicken & 13 & $\mathrm{O}$ & $92.6 \pm 21.5$ & Velogenic \\
\hline Cipunagara & Kp. Chicken & 14 & $\mathrm{O}$ & $76.3 \pm 1.2$ & Mesogenic \\
\hline Subang & Kp. Chicken & 15 & $\mathrm{C}$ & $117 \pm 0.0$ & Velogenic \\
\hline Subang & Kp. Chicken & 16 & $\mathrm{C}$ & $162 \pm 0.0$ & Velogenic \\
\hline
\end{tabular}

$\mathrm{Kp}=$ kampong, 10a and $10 \mathrm{~b} ; 12 \mathrm{a}$ and $12 \mathrm{~b}=$ from the same individual

$10 \mathrm{a}$ and 10b) and isolates obtained from cloacal and oropharyng swabs from 1 native chicken in Pagaden area (isolate $12 \mathrm{a}$ and $12 \mathrm{~b}$ ) were included to the same strain that was mesogenic/mesogenic and velogenic/velogenic, and $\mathrm{HI}$ titre from each isolate also had the same value. It indicated that both of excreted isolates from cloacal and oropharinx from 1 individual were the same NDV, but to confirm the virus identity, it needs to be sequenced. Elution time may be affected by temperature. According to Hussain et al. (2008) the elution time will be longer at $4^{\circ} \mathrm{C}$ and will be faster when the temperature is raised, therefore in order to obtain an accurate results, the elution test should be performed at a steady temperature. Besides, the elution test was also influenced by the concentration of red blood cells, if there are too many red blood cells during the testing, the red blood cells are not able to be bound by the virus, so that looks like a reaction to release of red blood cells by the virus and this will reduce the efficiency of elution test (Ezeibe \& Ndip 2004).

\section{Characterization of ND Virus by rRT-PCR fusion (F)}

Characterization of 18 isolates by rRT-PCR fusion (F) showed positive result for all isolates, indicating that all isolates were virulent virus strain. The result of rRT-PCR F test showed there was a correlation with the result of elusion time test where was obtained mesogenic isolates and 15 velogenic isolates, this is correspond with the result of rRT-PCR F that showed all isolates were positive for virulent NDV strain. Not all virulent NDV may be detected by rRT-PCR using primer fusion (F). According to Kim et al. (2006) specificity in molecular diagnostic tests, may be affected by nonconformities between nucleotide pairs of primer base and probe with sequence that have a potential to give a fake negative result, while according to Cattoli et al. (2011) high degree of nucleotide variation in gen $\mathrm{F}$ may cause incompatibility between the primers and probes with the NDV amino acid 
sequence. The incompatibility of primer oligobucleotide cause hybridization between primer/probe with RNA of virus not occurs, so it was not detected by real-time PCR system software.

\section{CONCLUSION}

Newcastle disease was still endemic in Subang area and the infection may be subclinical. Eighteen ND viruses which were found, majority had relatively homogeneous character, just a few isolates that showed diversity of pathogenicity and antigenicity (antisera LaSota: isolate 1, 2, and 3; antisera Komarov: isolate 3, 6 and 16). The ducks from Cipeundeuy area had not been exposed of NDV. The distribution of antibody titres in vaccinated chicken was unequal. The result of this study contributed information about ND in Subang area and may be used as feedback for Subang government to determine the prevention and control programs of ND infection in poultry in Subang.

\section{RECOMMENDATION}

Further research needs to be done to see the acidbase sequences of cleavage site of fusion (f) protein by sequencing or pathotyping test (MDT, ICPI, and IVPI) in order to obtain more information about pathogenicity and NDV strains which spread in Subang area. Sequencing needs to be done to see mutation in hemaglutinin. Strict sanitary and vaccinate use a combination of homologous live and inactive vaccine with field NDV can be applied to prevent ND infection in birds in Subang. Besides, more extensive surveys with more samples needs to be done to get information about infection of NDV that cover all areas in Subang area.

\section{REFERENCES}

Adi AAAM, Astawa NM, Putra KSA, Hayashi Y, Matsumoto Y. 2010. Isolation and characterization of a pathogenic Newcastle disease virus from a natural case in Indonesia. J Vet Med Sci. 72:313-319.

Adu FD. 1985. Characteristics of Nigerian strains of Newcastle disease virus. Avian Dis. 29:49-851.

Al-Garib SO, Gielkens ALJ, Gruys E, Hartog L, Koch G. 2003. Immunoglobulin class distribution of systemic and mucosal antibody responses to Newcastle disease in chickens. Avian Dis. 47:32-40.

Aldous EW, Alexander DJ. 2001. Detection and differentiation of Newcastle disease virus (avian paramyxovirus type 1). Avian Pathol. 30:117-128.

Alexander DJ, Bell JG, Alders RG. 2004. A Technology Review: Newcastle Disease, with Special Emphasis on
Its Effect on Village Chickens. Rome: FAO Animal Production and Health.

Alexander DJ, Senne DA. 2008. Newcastle disease and other paramyxovirus infections. In: A Laboratory Manual for the Isolation, Identification and Characterization of Avian Pathogens. In: Zavala LD, editor. Athens, GA American Association of Avian Pathologists. p. 135141.

Ashraf A, Shah MS. 2014. Newcastle Disease: Present status and future challenges for developing countries. Afr J Microbiol Res. 8:411-416.

Aziz TAG, Ahmed TA. 2010. Serological survey of Newcastle disease in domestic chickens in Sulaimani province. JZS. 13:31-38.

[BPPV] Balai Penyidikan dan Pengujian Veteriner Subang. 2011. Laporan Tahunan 2011. Subang (Indones): Balai Penyidikan dan Pengujian Veteriner.

[BPPV] Balai Penyidikan dan Pengujian Veteriner Subang. 2012. Laporan Tahunan 2012. Subang (Indones): Balai Penyidikan dan Pengujian Veteriner.

[BPPV] Balai Penyidikan dan Pengujian Veteriner Subang. 2013. Laporan Tahunan 2013. Subang (Indones): Balai Penyidikan dan Pengujian Veteriner.

Boven Mv, Bouma A, Fabri THF, Katsma E, Hartog L, Koch G. 2008. Herd immunity to Newcastle disease virus in poultry by vaccination. Avian Pathol. 37:1-5.

Brown C, King DJ, Seal BS. 1999. Pathogenesis of Newcastle disease In chickens experimentally Infected with viruses of different virulence. Vet Pathol. 36:125132.

Buckles E, Ruiz J, Korich J, Torres A, Banda A, Mondal S, Lucio-Martínez B. 2005. Atlas of avian disease. Ed ke-7. New York (US): Cornell University College of Veterinary Medicine.

Cattoli G, Susta L, Terregino C, Brown C. 2011. Newcastle disease: a review of field recognition and current methods of laboratory detection. J Vet Diagn Invest. 23:637-656

Cornax I, Miller PJ, Afonso CL. 2012. Characterization of live LaSota vaccine strain-induced protection in chickens upon early challenge with a virulent Newcastle disease virus of heterologous genotype. Avian Dis. 56:464-470.

[CVL] Central Veterinary Laboratory. 2007. Standard operating procedure for real time polymerase chain reaction detection of virulent Newcastle disease virus in clinical specimens.

Daulay S. 2005. Peluang dan potensi burung liar dalam penyebaran Newcastle disease di Sulawesi Selatan (Disertasi). [Bogor (Indones)]: Institut Pertanian Bogor.

Degefa T, Dadi L, Yami A, Mariam G, M Nassir. 2004. Technical and economic evaluation of different methods of Newcastle disease vaccine administration. J Vet Med Physiol Pathol Clin Med. 51:365-369. 
[DISNAK] Dinas Peternakan Kabupaten Subang. 2010. Kasus ND di Kabupaten Subang. Laporan Tahunan Dinas Peternakan Subang Tahun 2010. Subang (Indones): Dinas Peternakan Kabupaten Subang.

[DISNAK] Dinas Peternakan Kabupaten Subang. 2013. Laporan Tahunan Dinas Peternakan Subang Tahun 2013. Subang (Indones): Dinas Peternakan Kabupaten Subang.

Dortmans JCFM, Peeters BPH, Koch G. 2012. Newcastle disease virus outbreaks: Vaccine mismatch or inadequate application?. J Vet Microbiol. 160:17-22.

Emilia. 2013. Isolasi dan karakterisasi biologik Virus Newcastle Disease (NDV). (Tesis). [Bogor (Indones)]: Institut Pertanian Bogor.

Erf GF. 2004. Cell-mediated immunity in poultry. Poult Sci. 83:580-590.

Ezeibe MCO, Ndip ET. 2005. Differences in the red blood cell elution times of strains of Newcastle disease virus. AJOL. 22:99-101.

Ezeibe MCO, Ndip ET. 2005. Red blood cell elution time of strains of Newcastle disease virus. J Vet Sci. 6:287288.

Haque MH, Hossain MT, Islam MT, Zinnah MA, Khan MSR, Islam MA. 2010. Isolation and detection of Newcastle disease virus from field outbreaks in broiler and layer chickens by reverse transcription-polymerase chain reaction. Bangladesh J Vet Med. 8:87-92.

Hsiang-Jung T, Kuo-Hui C, Chun-Hsien T, M FK, Manvell RJ, Alexander DJ. 2004. Antigenic and genotypical characterization of Newcastle disease viruses isolated in Taiwan between 1969 and 1996. Vet Microbiol. 104:19-30.

Hu S, Wang T, Liu Y, Meng C, Wang X, Wu Y, Liu X. 2010. Identification of a variable epitope on the Newcastle disease virus hemagglutinin-neuraminidase protein. Vet Microbiol. 140:92-97.

Hu Z, Hu S, Meng C, Wang X, Zhu J, Liu X. 2011. Generation of a genotype VII Newcastle disease virus vaccine candidate with high yield in embryonated chicken eggs. Avian Dis. 55:391-397.

Hussain M, Mehmood MD, Ahmad A, Shabbir MZ, Yaqub T. 2008. Factors affecting hemagglutination activity of Avian Influenza virus subtype H5N1. J Vet Anim Sci. 1:31-36.

Ibu JO, Okoye JOA, Fasina FO, Aba-Adulugba EP, Abechi AS, Woma YT. 2008. Antigenic relatedness among Newcastle disease virus isolates from Nigerian feral birds and the La sota strain. Vet Sci. 13:79-84.

Indriani R, Dharmayanti NLPI, Adjid RMA. 2014. Efikasi penerapan vaksin AI H5N1 clade 2.1.3 pada itik Mojosari terhadap tantangan virus AI H5N1 clade 2.3.2 pada kondisi laboratorium. JITV. 19:59-66.

Kapczynski DR, King DJ. 2005. Protection of chicken against overt clinical disease and determination of viral shedding following vaccination with commercially available Newcastle disease virus vaccines upon challenge with highly virulent virus from the California 2002 exotic Newcastle disease outbreak. Vaccine. 23:3424-3433.

Kencana GAY, Kardena IM, Mahardika IGNK. 2012. Peneguhan diagnosis penyakit Newcastle disease lapang pada ayam bupurebred di Bali menggunakan teknik RT-PCR. J Kedokteran Hewan. 6:28-31.

Kim LM, Afonso CL, Suarez DL. 2006. Effect of Probe-Site Mismatches on detection of virulent Newcastle disease viruses using a fusion-gene real-time reverse transcription polymerase chain reaction test. J Vet Diag Invest. 18: 519-528.

Miller PJ, Afonso CL, Attrache JE, Dorsey KM, Courtney SC, Zijing G, Kapczynski DR. 2013. Effects of Newcastle disease virus vaccine antibodies on the shedding and transmission of challenge viruses. Dev Comp Immun. 41:505-513.

Miller PJ, Estevez C, Yu Q, Suarez DL, J KD. 2009. Comparison of viral shedding following vaccination with inativated and live Newcastle disease vaccines formulated with wild-type and recombinant viruses. Avian Dis. 53:39-49.

[NVSL] National Veterinary Services Laboratories. 2005. Real-Time RT-PCR for detection of virulent Newcastle disease virus in clinical samples.

Numan M, Zahoor MA, Khan HA, Siddique M. 2005. Serologi status of Newcastle disease in broilers and layers in Faisalabad and surrounding districts. Pak Vet J. 25:55-58.

[OIE] Office International des Epizooties. 2008. Manual of diagnostic tests and vaccines for terrestrial animals.

[OIE] Office International des Epizooties. 2009. NDV in Indonesia.

[OIE] Office International des Epizooties. 2012. Newcastle Disease.

Perozo F, Marcano R, Afonso CL. 2012. Biological and phylogenetic characterization of a genotype VII Newcastle disease virus from Venezuela: efficacy of field vaccination. J Clin Microbiol. 50:1204-1208.

Pertulla L. 2009. Epidemiology and Characterization of Newcastle disease in Smallholder Poultry in Mozambique. 1-21.

Reynolds DL, Maraqa AD. 2000. Protective immunity against Newcastle disease: the role of antibodies specific to Newcastle disease virus polypeptides. Avian Dis. 44:138-144.

Rezaeianzadeh G, Dadpurebred H, Safar A, Ali M, Hossein M, Nazemshirazi. 2011. Serological and molecular study of Newcastle disease virus circulating in village chicken of Fars Province, Iran. J Vet Med Anim Health. 3:105-111.

Saepulloh M, Darminto. 2005. Kajian Newcastle disease pada itik dan upaya pengendaliannya. Wartazoa. 15:84-94. 
Samal SK. 2011. Newcastle disease and related avian paramyxovirus. In: The Biology of Paramyxovirus. Norfolk (UK): Caister Academic Press. p. 69-114.

Senne DA, King DJ, Kapczynski DR. 2004. Control of Newcastle disease by vaccination. Dev Biol. 119:165170.

Sheffield FW, Smith W, Belyavin G. 1954. Purification of Influenza virus by red-cell adsorption and elution. $35: 214-222$

Syukron MU, Suartha IN, Dharmawan NS. 2013. Serodeteksi penyakit tetelo pada ayam di Timor Leste. Indones Med Vet. 2:360-368.
Wise MG, Suarez DL, Seal BS, Pedersen JC, Senne DA, King DJ, Kapczynski DR, Spackman E. 2004. Development of a Real-Time Reverse-Transcription PCR for detection of Newcastle disease virus RNA in clinical samples. J Clin Microbiol. 42:329-338.

Xiao S. 2012. Complete Genom Sequences of Newcastle Disease Virus Strain Circulating in Chickens Populations of Indonesia. J Virol. 86:5969-5970.

Yan Z, Du Y, Zhao Q, Fan R, Guo W, Ma R, Wang X, Zhu R. 2011. Mucosal immune responses against live Newcastle disease vaccine in immuno suppressed Chickens. Pak Vet J. 31:280-286. 